pISSN: 2442-3386 elSSN: 2442-4293

Vol 6 No 1 Januari 2020, 9 - 16

\title{
SISTEM INFORMASI PENJUALAN KOSMETIK
}

\author{
Vivin Antika ${ }^{1}$, Emmy Wahyuningtyas ${ }^{2}$ \\ Program Studi Teknik Informatika, Fakultas Teknik, Universitas Wijaya Kusuma Surabaya \\ ${ }^{1}$ vivinantika7@gmail.com, ${ }^{2}$ Emmy@if.uwks.ac.id
}

\begin{abstract}
Abstrak
Sistem Informasi Penjualan Kosmetik berbasis web adalah sebuah sistem informasi yang menyediakan atau menjual produk-produk kosmetik. Akan tetapi banyak web yang hanya menjual kosmetik tetapi tidak memenuhi kebutuhan konsumen. Walaupun sudah terdapat sistem informasi penjualan kosmetik, konsumen tetap mengikuti seminar atau kelas yang diadakan secara offline oleh penyelenggara untuk menambah pengetahuan tentang kosmetik. Penelitian ini bertujuan untuk membuat Sistem Informasi Penjualan yang bisa menyelesaikan kendalakendala yang dialami oleh konsumen. Kebutuhan sistem ini diantaranya konsumen dapat mengikuti seminar online, dapat berinteraksi dengan sesama konsumen melalui dunia maya dan konsumen dapat mengikuti kelas kecantikan secara online. Hasil dari penelitian ini berupa Sistem Informasi Penjualan Kosmetik yang meliputi katalog penjualan, fitur seminar online, fitur beauty class online, fitur forum diskusi online dan pembayaran.
\end{abstract}

Kata Kunci : Sistem Informasi, Penjualan, Kosmetik, Web, E-commerce

\begin{abstract}
Web-based Cosmetic Sales Information System is an information system that provides or sells cosmetic products. However, many websites only sell cosmetics but do not meet the needs of consumers. Even though there is a cosmetics sales information system, consumers continue to attend seminars or classes held offline by the organizer to increase knowledge about cosmetics. This study aims to create a Sales Information System that can solve the constraints experienced by consumers. These system needs include consumers being able to take part in online seminars, being able to interact with fellow consumers through cyberspace and consumers being able to take beauty classes online. The results of this study are Cosmetic Sales Information Systems which include sales catalogs, online seminar features, online beauty class features, online discussion forum features, and payments.
\end{abstract} Keywords: Information Systems, Sales, Cosmetics, Web, E-commerce

\section{PENDAHULUAN}

Penjualan merupakan faktor penting dalam kemajuan dan perkembangan perusahaan, karena pendapatan yang diperoleh dari hasil penjualan digunakan untuk membiayai kelangsungan perusahaan, terlebih dalam menghasilkan keuntungan. Oleh karena itu wajar jika perusahaan mempertimbangkan pentingnya peranan sistem informasi penjualan. Sistem informasi penjualan adalah suatu sistem informasi yang mengorganisasikan serangkaian prosedur dan metode yang dirancang untuk menghasilkan, menganalisa, menyebarkan dan memperoleh informasi guna mendukung pengambilan keputusan mengenai penjualan (Nore, 2013). Sistem informasi penjualan online merupakan sebuah sistem yang memudahkan masyarakat berbelanja.

Sistem informasi penjualan kosmetik berbasis web sudah banyak beredar di internet. Dari survei yang dilakukan oleh peneliti, terdapat beberapa hasil yang ditemukan dari masing-masing web tersebut. Beberapa diantaranya adalah dari web www.belanjamimo.com, dari web tersebut tidak memiliki list yang digunakan untuk mengurutkan harga dari yang terendah ke tinggi ataupun sebaliknya, yang akan membuat konsumen kesulitan mencari kosmetik dengan harga yang paling rendah. Dan juga pada web tersebut tidak dilengkapi dengan informasi yang berupa artikel untuk menambah wawasan konsumen. Web tersebut juga tidak dilengkapi dengan live chat atau sejenisnya yang dapat digunakan untuk komunikasi konsumen dangan penjual atau antar sesama konsumen. Dari web www.pusatkosmetik.com, pada web ini tidak terdapat artikel, saran penggunaan ataupun kelas yang memudahkan konsumen untuk mencari informasi tentang produk yang dicari. Pada web makeupuccino.com, tidak ada informasi tentang kelas yang dilakukan secara online, tidak ada komunikasi yang dilakukan antar sesama konsumen untuk saling bertukar informasi. Semakin berkembangnya teknologi maka semakin banyak sistem infromasi penjualan kosmetik yang berkembang, akan tetapi tidak memenuhi kebutuhan konsumen. Walaupun sudah terdapat 
sistem informasi penjualan kosmetik, konsumen tetap mengikuti seminar atau kelas yang diadakan secara offline oleh penyelenggara untuk menambah pengetahuan tentang kosmetik.

Berdasarkan permasalahan yang telah dikemukakan, diperlukan adanya solusi dalam memecahkan masalah yang ada. Tidak adanya fitur bagi konsumen untuk saling bertukar informasi, tidak adanya fitur bagi konsumen untuk berkonsultasi atau mempelajari cara menggunakan atau memilih kosmetik yang benar dari ahli secara langsung. Dengan adanya sistem informasi penjualan kosmetik yang memiliki fitur-fitur tersebut, konsumen tidak perlu datang ke toko, penjual dapat berinteraksi dengan konsumen melalui dunia maya, bahkan memungkinkan untuk sesama konsumen saling berinteraksi melalui fitur tersebut. Atau konsumen dapat bertemu dengan ahli kecantikan untuk berkonsultasi atau bahakan melakukan kelas kecantikan secara online. Untuk itu peneliti mengusulkan sebuah sistem yang mempunyai fitur beauty class online, seminar online dan forum diskusi online.

\section{TINJAUAN PUSTAKA}

Sistem informasi adalah kumpulan data yang terintegrasi dan saling melengkapi dengan menghasilkan output yang baik guna untuk memecahkan masalah dan pengambilan keputusan.

Menurut Yulianti dan Furqon (Yulianti, 2013), "sistem informasi penjualan adalah sistem informasi yang menyangkut pengolahan data penjualan. Dengan transakasi, mendukung operasi, bersifat manajerial dan kegiatan strategi dari suatu sistem penjualan dan menyediakan pihak luar tertentu dengan laporan - laporan yang diperlukan.

Berdasarkan berbagai pengertian dari para ahli, penulis dapat mengambil kesimpulan bahwa sistem informasi penjualan merupakan sistem yang berfungsi untuk mengolah data - data terkait dengan penjualan dengan menggunakan serangkaian prosedur untuk mendukung kegiatan penjualan.

\section{HASIL DAN PEMBAHASAN}

Penelitian sistem informasi penjualan kosmetik secara online melalui beberapa tahapan, hal ini dilakukan supaya penelitian yang dihasilkan lebih baik sesuai dengan tujuan dari analisa sistem. Tahapan dari penelitian digambarkan dalam sebuah diagram alur penelitian berikut:

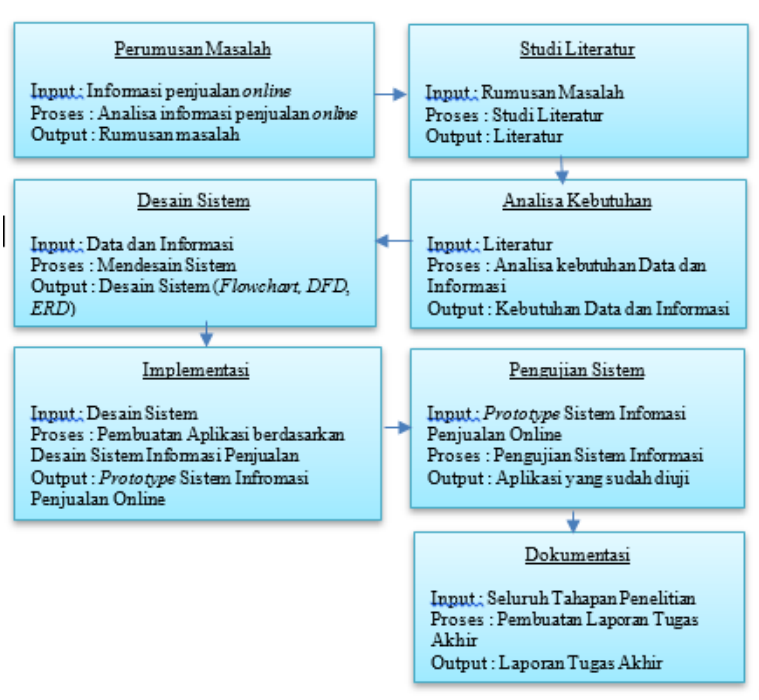

Gambar 1 Diagram Alur Penelitian.

\subsection{Perumusan Masalah}

Dalam pembuatan Tugas Akhir, tahap ini adalah kegiatan mencari sebanyak-banyaknya permasalahan. Rumusan permasalahan berdasarkan pada masalah pokok yang terdapat pada bagian latar belakang masalah. Masalah-masalah yang hendak dikemukakan pada bagian ini dirumuskan dalam kalimat pertanyaan yang singkat dan sederhana.

Batasan masalah mempunyai kaitan dengan rumusan masalah. Belum tentu masalah-masalah yang telah diidentifikasikan dapat diteliti. Keterbatasan mahasiswa memungkinkan masalah yang telah diidentifikasi itu tidak dapat diteliti semuanya namun hanya sebagian saja. Bahasa lain batasan ini adalah ruang lingkup. Bila anda memiliki keterbatasan dalam waktu, pemikiran, data dan biaya, maka ruang lingkup yang anda miliki akan sempit. Manfaat lain dari ruang lingkup yang sempit adalah kupasan materi nantinya sangat rapat sehingga tidak akan kerepotan dalam mempetahankannya didepan dewan penguji.

Pada tahap perumusan masalah, penulis melakukan pengamatan terhadap sistem informasi penjualan kosmetik lain dan mendapati beberapa kekurangan atau masalah pada sistem yang dapat dibuat lebih efisien, oleh sebab itu pada tahap ini penulis menentukan beberapa rumusan masalah sesuai hasil dari pengamatan untuk dijadikan acuan dan tujuan penelitian.

\subsection{Studi Literatur}

Pada tahap ini, peneliti mencari dan mengumpulkan data yang akan dijadikan obyek pembuatan sistem berbasis web dari berbagai sumber. Contohnya, dari jurnal ilmiah, arikel, skripsi maupun buku - buku referensi 


\section{pISSN: 2442-3386 elSSN: 2442-4293}

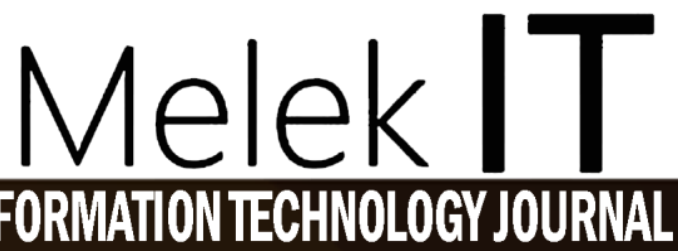

\subsection{Desain Sistem}

Setelah tahap pengolahan data selesai dilakukan, maka analis sistem telah mendapatkan gambaran dengan jelas apa yang harus dikerjakan.

Pada tahap ini, penulis mulai membuat desain sistem yang berisikan desain ERD, DFD, Flowchart dan kebutuhan perangkat keras serta biaya pembuatan dari sistem berdasarkan pengolahan data yang telah dilakukan. Tools yang digunakan untuk mendesain ERD, Flowchart dan DFD adalah PowerDesigner 16.5 dan Microsoft Office Visio 2017.

\subsubsection{DFD level context}

Pada DFD Level Context sistem informasi penjualan kosmetik berbasis web ini menggambarkan aliran proses secara umum antara pembeli dan penjual. DFD Level Context sistem ini akan ditampilkan pada gambar 3.2 berikut

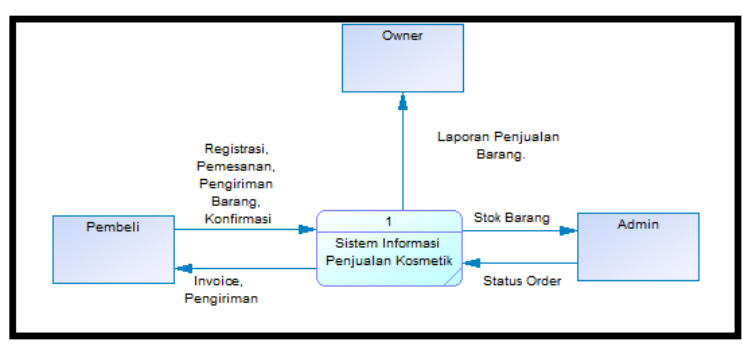

Gambar 2 DFD level context.

Pada sistem informasi penjualan kosmetik ini terdapat 3 fitur yaitu fitur forum diskusi online, fitur seminar online dan fitur beauty class online.

a. Fitur forum diskusi online

Pada fitur ini pengguna dapat berkomunikasi dengan pengguna lain dengan menambahkan topik untuk dibahas di dalam forum.

b. Fitur seminar online

Pada fitur seminar online ini pengguna mendapatkan promosi dari harga produk yang dipromosikan, sertifikat yang akan diterima secara online dan pengguna dapat mencetak sendiri sertifikat yang telah didapatkan. Untuk notifikasi dari seminar online ini menggunakan email.

c. Fitur beauty class online

Pada fitur beauty class online ini pengguna mengikuti kelas secara virtual. Disini pengguna mendapatkan hasil akhir berupa seftifikat atau ijazah sebagai bukti bahwa telah mengikuti kelas hingga selesai. Notifikasi dari kelas online ini menggunakan alamat email yang didaftarkan telah pengguna.

\subsection{Flowchart}

Dalam desain sistem terdapat proses bisnis sistem informasi penjulana kosmetik yang dijabarkan kedalam bentuk flowchart berikut:

a. Flowchart proses bisnis pemesanan

Di dalam sistem informasi penjualan kosmetik, salah satunya terdapat proses bisnis pemesanan seperti berikut:

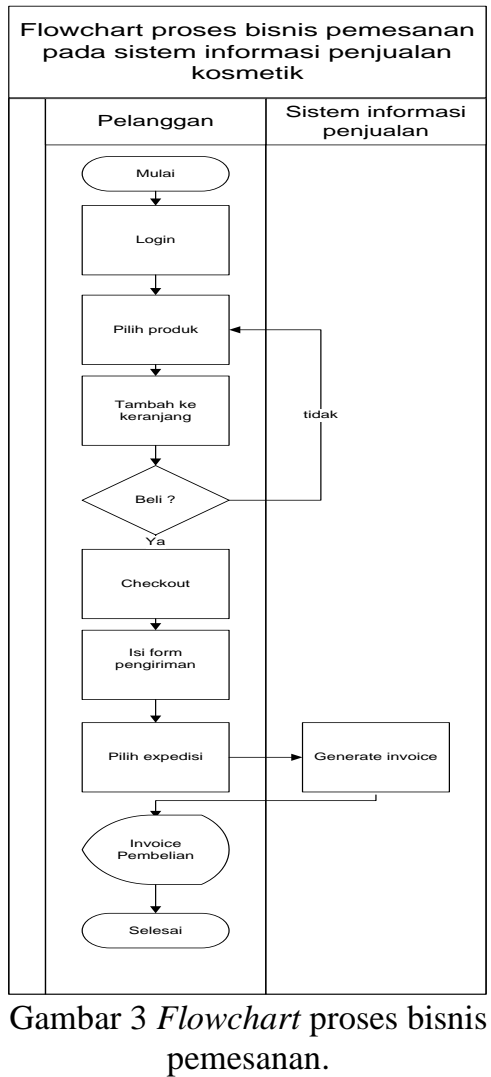

Pada gambar 3 menjelaskan tentang proses bisnis pemesanan. Pelanggan melakukan login terlebih dahulu dengan catatan telah melakukan registrasi akun sebelumnya. Setelah login pelanggan dapat langsung memilih produk dan menambahkan ke keranjang belanja. Jika pelanggan ingin melanjutkan pembelian maka pilih checkout, jika tidak maka pelanggan akan kembali memilih produk. Setelah checkout, pelanggan diwajibkan mengisi form pengiriman. Selanjutnya pelanggan memilih exspedisi mana yang digunakan untuk mengirim produk. Selanjutnya sistem akan mengenerate invoice dan mengirimkannya ke pelanggan, jika pelanggan sudah menerima invoice, maka 
proses pemesanan produk pada sistem informasi penjualan kosmetik telah selesai.

b. Flowchart proses bisnis pembayaran

Pada sistem informasi penjualan kosmetik terdapat proses bisnis pembayaran. Setelah pemesanan proses selanjutnya adalah pembayaran yang akan dijelaskan pada gambar flowchart berikut:

Flowchart proses bisnis pembayaran pada sistem informasi penjualan kosmetik

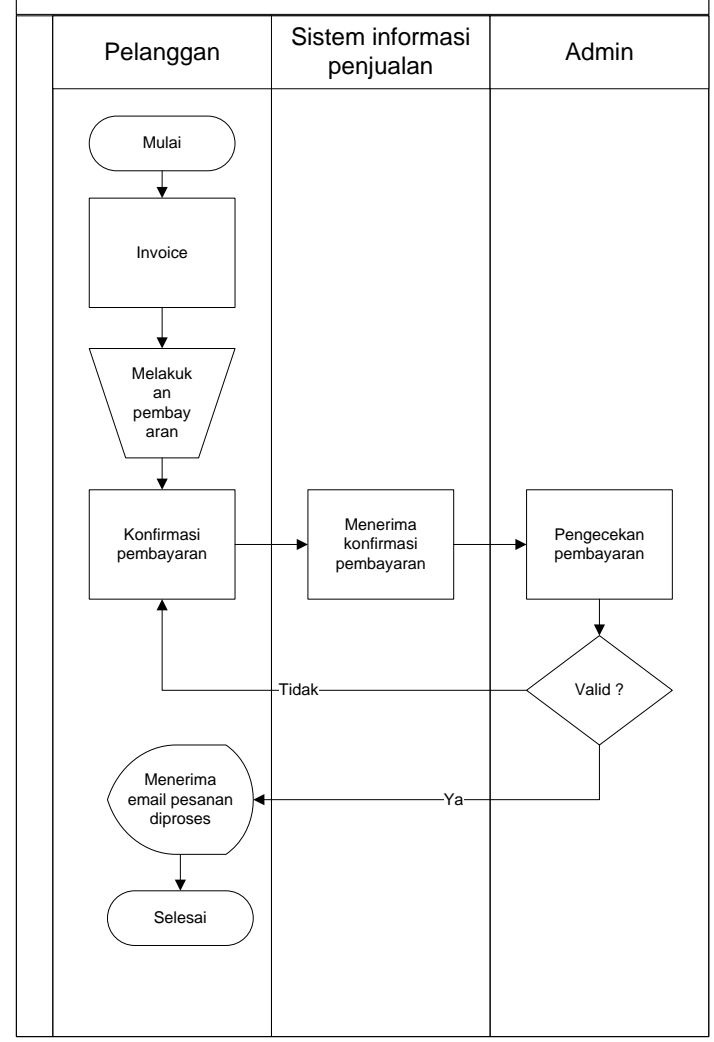

Gambar 4 Flowchart proses bisnis pembayaran.

Pada gambar 4 menjelaskan tentang proses bisnis pembayaran. Setelah pelanggan menerima invoice, maka selanjutnya pelanggan melakukan pembayaran secara manual melalui transfer bank yang telah disediakan nomor rekeningnya oleh admin. Setelah melakukan pembayaran pelanggan melakukan konfirmasi pembayaran melalui pesan yang dikirim lewat email dan sistem akan menerima konfirmasi pembayaran tersebut. Setelah itu admin melakukan pengecekan apakah pelanggan telah melakukan pembayaran, jika belum maka pelanggan akan menerima pesan untuk konfirmasi pembayaran melalui email. Jika pelanggan sudah melakukan pembayaran maka pelanggan akan menerima email bahwa pesanan sedang diproses.

\subsection{Entity Relationship Diagram (ERD)}

Berikut merupakan hasil rancangan dari entitiy relationship diagram yang mengacu pada sistem informasi penjualan kosmetik.

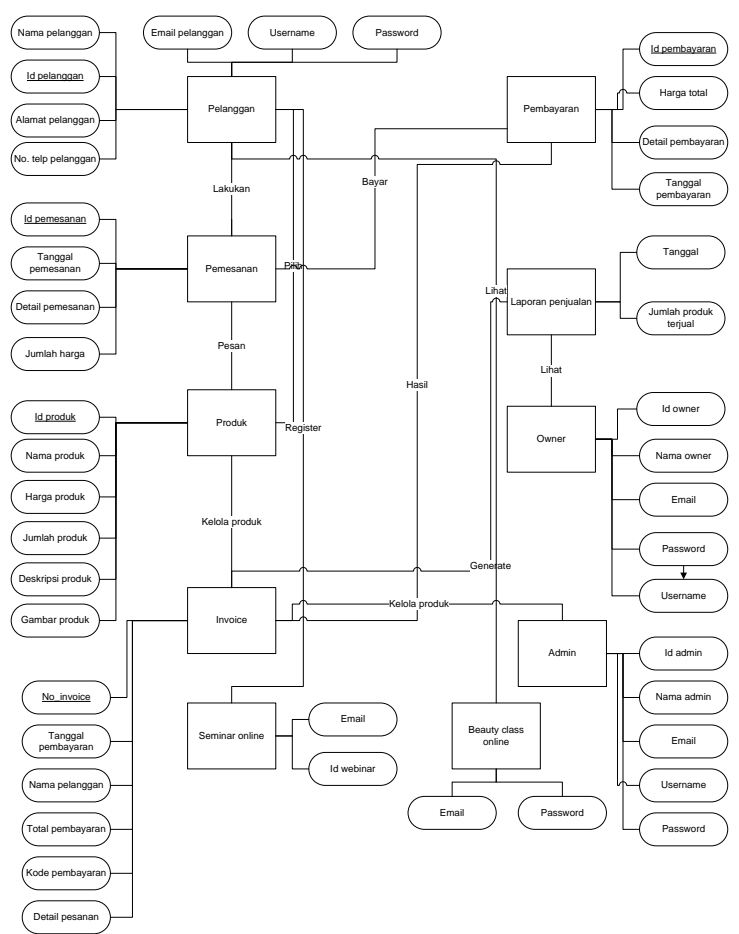

Gambar 5 Entity relationship diagram.

Pada gambar 5 merupakan gambaran dari entity relationship diagram yang mengacu pada sistem informasi penjualan kosmetik. Pada ERD diatas memiliki 8 entitas yaitu, pelanggan, pemesanan, pembayaran, laporan penjualan, produk, owner, invoice dan admin. Pada entitas pelanggan memiliki atribut nama pelanggan, id pelanggan, lamat pelanggan, no. Telp pelanggan, email pelanggan, username dan password. Pada entitas pemesanan memiliki atribut id pemesanan, tanggal pemesanan, detail pemesanan, dan jumlah harga. Pada entitas pembayaran memiliki atribut id pembayaran, harga total, detail pembayaran dan tanggal pembayaran. Pada entitas produk memiliki atribut id produk, nama produk, harga produk, jumlah produk, deskripsi produk dan gambar produk. Pada entitas laporan penjualan memiliki atribut tanggal dan jumlah produk terjual. Pada entitas owner memiliki atribut id owner, nama owner, email owner, password owner dan username. Pada entitas invoice memiliki atribut no invoice, tanggal pembayaran, nama pelanggan, total pembayaran, kode pembayaran dan detail pesanan. Pada entitas admin memiliki atribut id admin, nama admin, email, username dan password.

Pada entitas pelanggan dan pemesanan memiliki relasi yang bernama lakukan, pada entitas 


\section{pISSN: 2442-3386 elSSN: 2442-4293}

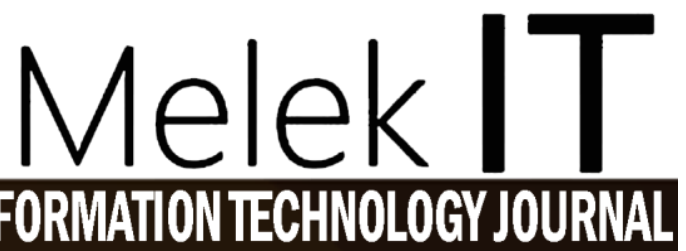

\section{Vol 6 No 1 Januari 2020, 13 - 16}

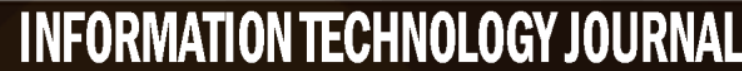

pelanggan dengan entitas produk memiliki relasi pilih, pada entitas pemesanan dan entitas pembayaran memiliki relasi bayar, pada entitas invoice dan entitas pembayaran memiliki relasi hasil, pada entitas invoice dengan entitas laporan penjulan memiliki relasi generate, pada entitas laporan penjualan dengan entitas owner memiliki relasi lihat, pada entitas produk dengan entitas admin memiliki relasi kelola produk.

\subsection{Conceptual Data Model (CDM)}

Berikut merupakan hasil rancangan dari conceptual data model mengacu pada sistem informasi penjualan kosmetik, yang memiliki 8 tabel yaitu tabel owner, tabel laporan penjualan, tabel invoice, tabel pembayaran, tabel pemesanan, tabel pelanggan, tabel produk dan tabel admin:

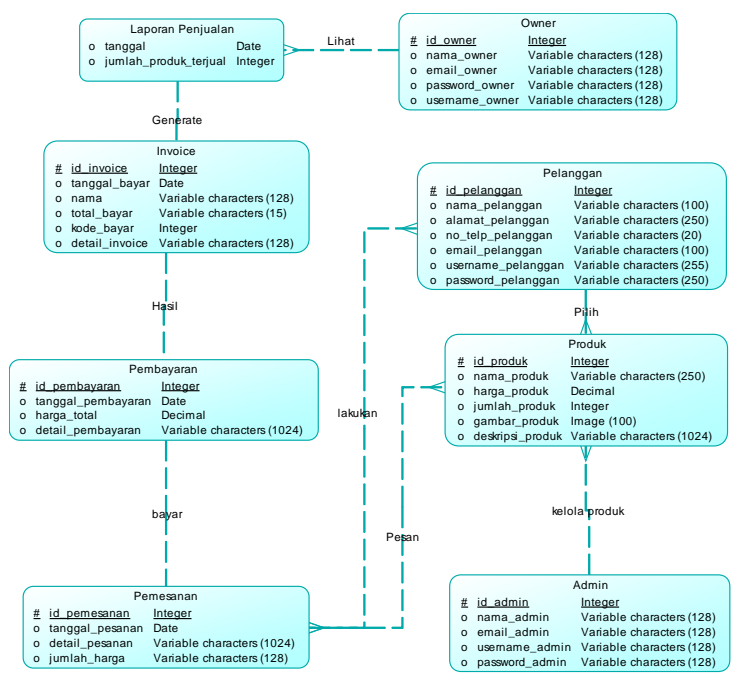

Gambar 6 conceptual data model

CDM memodelkan struktur logis dari keseluruhan aplikasi data, tidak tergantung pada software atau pertimbangan model struktur data. Conceptual data model dari gambar 6 mengacu dalam sistem informasi penjualan kosmetik yang dibuat. CDM pada sistem informasi penjualan kosmetik terdapat 8 tabel dimana nama tabel tersebut adalah tabel owner, tabel laporan penjualan, tabel invoice, tabel pelanggan, tabel pembayaran, tabel pemesanan, tabel produk dan tabel admin.

\subsection{Implementasi}

Implementasi rancangan membahas perancangan sistem dan hasil uji coba sistem. Perancangan sistem meliputi :

\subsubsection{Halaman Create Account}

Sebelum dapat mengakses modul-modul yang ada pada aplikasi sistem informasi penjualan kosmetik, user diharuskan terlebih dahulu melakukan pembuatan akun untuk bisa login. User juga diharuskan menggunakan alamat email yang masih aktif untuk proses validasi akun.

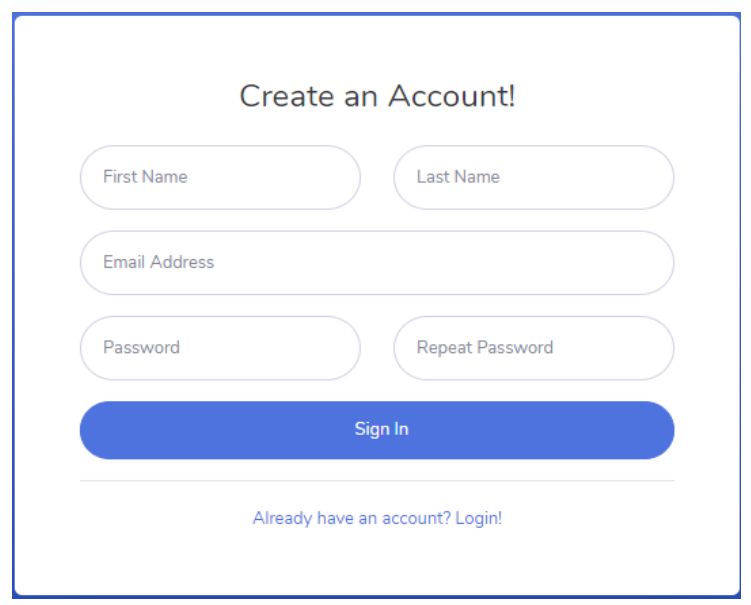

Gambar 7 halaman create account

\subsubsection{Halaman Login}

Sesudah melakukan pembuatan akun, maka user bisa melakukan login yang sudah dalam aplikasi. Halaman login ini digunakan oleh user yaitu admin, owner dan pelanggan.

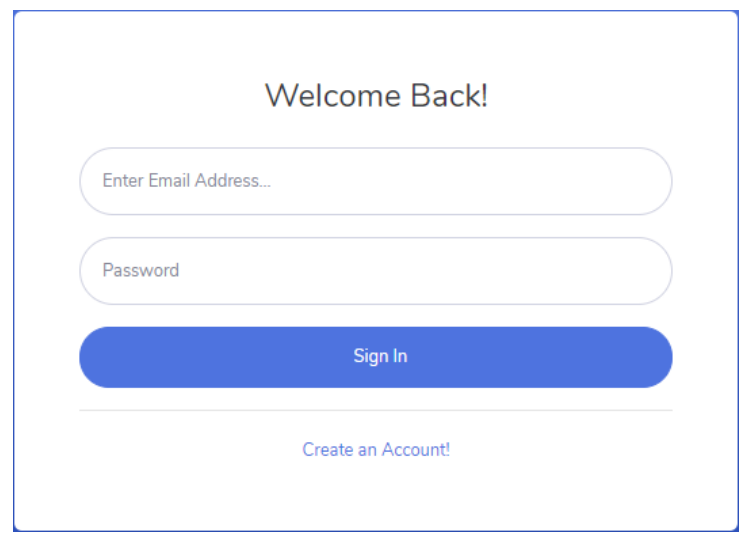

Gambar 8 halaman login.

\subsubsection{Halaman Katalog Penjualan}

Pada tampilan halaman katalog penjualan menunjukkan produk yang dijual. Pelanggan bisa memilih produk mana yang akan dibeli dengan melihat produk-produk yang tersedia disistem informasi penjualan kosmetik. Pelanggan juga dapat melihat produk yang dikelompokkan sesuai dengan kebutuhan wajah. Selain itu pelanggan juga dapat 
mengurutkan harga dari yang terendah ke yang tertinggi dan juga sebaliknya.

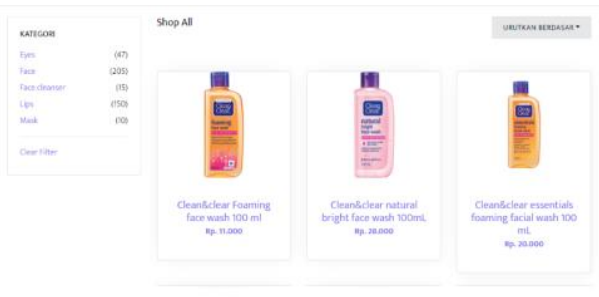

Gambar 9 halaman katalog penjualan.

\subsubsection{Halaman Admin}

Pada tampilan halaman ini menunjukan tampilan user interface pada admin sistem informasi penjualan kosmetik. Pada tampilan admin disediakan menu-menu yang ada di dashboard admin yaitu master user, master barang, master video dan laporan penjualan.

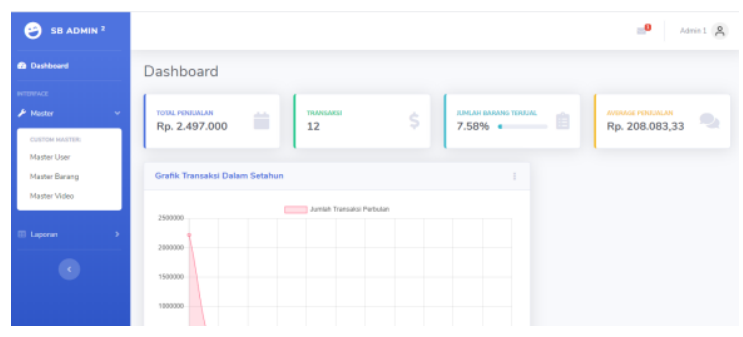

Gambar 10 halaman admin.

\subsubsection{Halaman Seminar Online}

Pada halaman seminar online pelanggan dapat ikut serta dalam seminar dengan menggunakan aplikasi webinar. Pelanggan dapat bergabung dengan menggunakan id webinar yang telah dibagikan oleh penyelenggara.
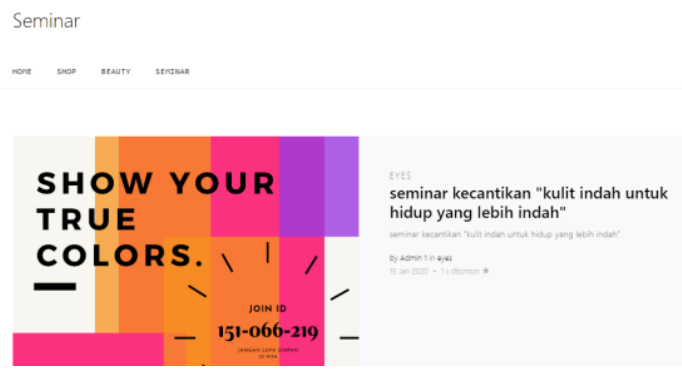

Gambar 11 Tampilan halaman seminar Online.

\subsubsection{Halaman Beauty Class Online}

Pada halaman beauty class online terdapat video tutorial dan tips-tips untuk penggunaan kosmetik. Dihalaman ini pelanggan dapat melihat video tutorial untuk belajar penggunaan kosmetik.
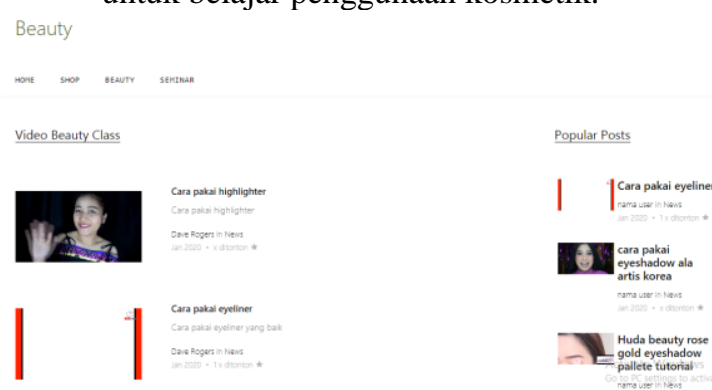

Gambar 12 Tampilan halaman Beauty Class

Online.

\section{PENUTUP}

\subsection{Kesimpulan}

Dari hasil dan Analisa terhadap sistem informasi penjualan kosmetik yang telah dibuat, didapat kesimpulan sebagai berikut:

1. Desain sistem informasi penjualan kosmetik berbasis web tampak lebih mudah diakses oleh user.

2. Memudahkan bagi pelanggan untuk mencari produk kosmetik.

3. Sistem ini dibuat untuk melakukan transaksi pembelian dan pemesanan produk yang dilakukan oleh pelanggan secara online.

\subsection{Saran}

Saran yang diberikan berdasarkan hasil Analisa implementasi yaitu:

1. gembangan sistem informasi penjualan agar dapat diakses melalui mobile phone.

2. Pengembangan cara penggunaan kosmetik dengan menggunakan deteksi foto pelanggan.

3. Pengembangan dengan menganalisa kembali apakah penggunaan fitur forum diskusi dan seminar online dapat mempermudah mempromosikan produk, perusahaan dapat menghemat biaya promosi dan perusahaan bisa mendapatkan keuntungan yang lebih banyak 
pISSN: 2442-3386 elSSN: 2442-4293

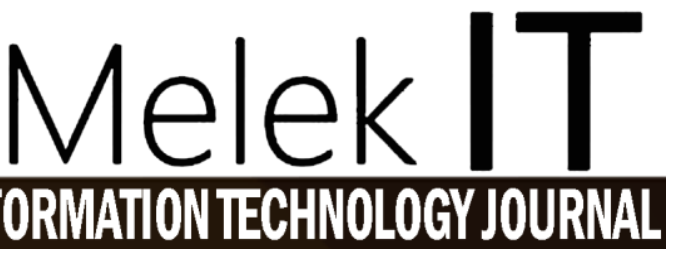

\section{DAFTAR PUSTAKA}

[1] Ahmadi, R. (2015). Bagus Dalam Seminar. Yogyakarta: Mediatama.

[2] Azwanti, N. (2017). Sistem Informasi Penjualan Tas Berbasis Web Dengan Pemodelan Uml. Kumpulan Jurnal Ilmu Komputer (KLIK), Vol. 04, No. 01.

[3] Ermatita. (2016). Analisis Dan Perancangan Sistem Informasi Perpustakaan. Jurnal Sistem Informasi (JSI), VOL . 8, NO. 1.

[4] H. Muhammad Subekti, B. M. (2004). Sistem Manajemen Basisdata. Ciawi: Ghalia Indonesia.

[5] Jeprie, M., H. Muhammad Subekti, B. M., \& Sutrisno, S. M. (2013). Cara Mudah Belajar Pemrograman Web Dengan Php. Makassar: Elex Media Komputindo.

[6] Kosasi, S. (2014). Pembuatan Sistem Informasi Penjualan Berbasis Web Untuk Memperluas Pangsa Pasar. Prosiding SNATIF.
[7] Lurking. (2014). Virtual Class. YH Works Press.

[8] Noviandhiny, P. (2018). Rancang Bangun Aplikasi Penjualan Dan Pembelian Berbasis Web Pada Apotek Neofarma Sanggau. JustIn (Jurnal Sistem dan Teknologi Informasi), Vol. 6, No. 3.

[9] Nugroho, B. (2015). Database Relasional Dengan Mysql. Yogyakarta: Penerbit Andi.

[10] Pramono, T. (2015). Sistem Informasi Penjualan. Yogyakarta: Skripta Media Creative

[11] Sagita, R. A., \& Sugiarto, H. (2016). Penerapan Metode Waterfall Pada Sistem Infomasi Penjualan Furniture Berbasis Web. IJNS (Indonesian Journal of Network and Security), Vol. 5, No. 4.

[12] Saragih, \& Hoga. (2014). Rencana Strategis Teknologi Informasi Dan Sistem Informasi Pada Proses Bisnis Perusahaan. Surabaya:

Graha

Ilmu. 


\section{Melek IT}

Information Technology Journal. Vol 6 No 1 Januari 2020, 16 - 16

Halaman ini kosong

Redaksi MelekIT 